\title{
Dukungan Sosial dan Penerimaan Diri Penderita Pascastroke
}

\author{
MAYA KHAIRANI*, AFRIANA SELVI AS, \& KARTIKA SARI \\ Program Studi Psikologi, Fakultas Kedokteran Universitas Syiah Kuala
}

\begin{abstract}
ABSTRAK
Penderita pascastroke mengalami perubahan fisik yang membuatnya menjadi lebih sensitif, sulit mengendalikan emosi, mudah putus asa, depresi sehingga tidak dapat menerima kelemahan dirinya. Oleh karenanya, penderita pascastroke membutuhkan dukungan sosial agar dapat menerima dirinya dengan baik. Penelitian ini bertujuan untuk mengetahui hubungan antara dukungan sosial dengan penerimaan diri pada penderita pascastroke. Penelitian melibatkan 75 penderita pascastroke dengan strategi incidental sampling. Untuk mengukur variabel penelitian, penulis menggunakan skala dukungan sosial dan skala penerimaan diri. Penulis menggunakan teknik korelasi Spearman's rho untuk menguji hipotesis dan analisis data menunjukkan adanya korelasi yang positif dan cenderung moderat antara dukungan sosial dengan penerimaan diri pada penderita pascastroke. Artinya, pasien dengan dukungan sosial yang cenderung tinggi juga memiliki penerimaan diri yang lebih baik.
\end{abstract}

Kata kunci: dukungan sosial, penerimaan diri, stroke

\begin{abstract}
Post-stroke patients experience physical changes that causes them to be more sensitive, difficult to control their emotions, easily discouraged, and depressed so that they cannot accept their weaknesses. Therefore, post-stroke patients need social support in order to accept themselves well. This research aimed to find out the relationship of social support with self-acceptance on post-stroke patients. This research involved 75 post-stroke patients collected by incidental sampling strategy. To measure variables of interest, the authors employed social support scale and self-acceptance Scale. The authors decided to use Spearman's rho correlation to test the hypothesis and data analysis a positive and moderate correlation between social support and self-acceptance among the post-stroke patients. Our findings imply that patients who had higher level of social support are those who also accepted themselves better.
\end{abstract}

Keywords: self-acceptance, social support, stroke

INSAN Jurnal Psikologi dan Kesehatan Mental, 2021, Vol. 6(1), 44-52, doi: 10.20473/jpkm.v6i12021.53-62 Dikirimkan: 02 Agustus 2018 Diterima: 08 Juli 2021 Diterbitkan: 12 Juli 2021

Editor: Rizqy Amelia Zein

*Alamat korespondensi: Jl. Tgk. Tanoeh Abee Fakultas Kedokteran Universitas, Kopelma Darussalam, Syiah Kuala, Banda Aceh 23111. Surel: khairani.maya@unsyiah.ac.id

Naskah ini merupakan naskah dengan akses terbuka dibawah ketentuan the Creative Common Attribution License (http://creativecommons.org/licenses/by/4.0), sehingga penggunaan, distribusi, reproduksi dalam media apapun atas artikel ini tidak dibatasi, selama sumber aslinya disitir dengan baik. 


\section{PE N D A H U L U A N}

Stroke atau Cerebral Vasculer Accident (CVA) merupakan suatu sindrom klinis dengan gejala berupa gangguan fungsi otak yang dapat menimbulkan kematian atau kelainan yang menetap lebih dari 24 jam. Stroke menjadi penyebab kematian ketiga tertinggi di dunia setelah penyakit kanker dan jantung. Di Amerika Serikat, ada kurang lebih lima juta orang yang pernah mengalami stroke dan dilaporkan bahwa prevalensi stroke adalah 35,6 per 100.000 penduduk. Setiap tahun, diperkirakan 500.000 penduduk terkena serangan stroke dan sekitar 2,5 persen atau 250.000 orang meninggal dunia sedangkan sisanya cacat ringan maupun berat (Ginsberg, 2008; Price \& Wilson, 2005). Stroke kemudian juga disebut sebagai salah satu penyakit kronis utama yang menyebabkan kelumpuhan bahkan kematian (terminal illness).

Kendati menyerang secara mendadak, stroke didahului oleh sejumlah gejala mulai dari ringan sampai terjadinya penurunan kesadaran dimana gejala yang umum terjadi adalah muncul gangguan pergerakan anggota gerak seisi tubuh, sering juga didapati gangguan panca indra, penglihatan kabur, dan pendengaran terganggu (Mahendra \& Rahmawati, 2007). Berdasarkan data dari Riset Kesehatan Dasar (Riskesdas, 2007), stroke menempati peringkat pertama sepuluh besar penyakit tidak menular di Indonesia dengan yaitu dengan proporsi 26,9 persen, dimana prevalensi stroke di Indonesia yang terjadi sebanyak 8,3 per 1.000 penduduk. Berdasarkan prevalensi stroke di Indonesia, Aceh menduduki peringkat tertinggi yaitu 16,6 persen. Berdasarkan data yang dikumpulkan di Rumah Sakit Umum Daerah Dr. Zainoel Abidin (RSUDZA) tahun 2007 sampai Februari 2010 dilaporkan bahwa penderita stroke meningkat setiap tahun dan total kasus sebanyak 879 kasus yang angka kematiannya sebanyak 124 dari total kasus (Buku Induk RSUDZA, n.d.).

Stroke dapat menyebabkan penderitanya mengalami kerusakan motorik, sensori, kognitif atau gangguan berbicara sebagai akibat dari kerusakan otak (Sarafino, 1998). Menurut Sofwan (2010) dampak stroke adalah kelumpuhan, perubahan mental seperti agnosia, anosia, ataksia, apraksia, dan distorsi spasial, gangguan komunikasi seperti disartia dan afasia, gangguan emosional, dan kehilangan indra rasa. Hal ini sesuai dengan penyataan Feigin (2006) yang menyebutkan bahwa stroke mengakibatkan individu mengalami keterbatasan dalam hidupnya. Gangguan fisik tersebut adalah adanya serangan defisit neurologis atau kelumpuhan fokal, baal atau mati rasa sebelah badan, mulut mencong, sulit untuk makan dan minum, mengalami kekakuan ataupun kesulitan ketika berjalan, pendengaran yang kurang baik, gerakan tidak terkoordinasi, dan gangguan kesadaran.

Sarafino (1998) menyatakan bahwa penyakit stroke dapat memengaruhi psikologis penderita pascastroke, ada beberapa masalah psikologis yang dirasakan oleh penderita pascastroke yaitu: kemarahan, isolasi, kelabilan emosi, kecemasan yang berlebihan dan depresi. Penderita pascastroke menghadapi banyak masalah fisik yang disertai dengan tekanan psikologis yang kemudian dapat mengakibatkan stres, menimbulkan perasaan-perasaan kecewa, tertekan, susah, sedih, cemas, marah, malu, terhina, rendah diri, putus asa, hampa, tidak bermakna, serta penghayatan-penghayatan tidak menyenangkan lainnya (Darusman, 2008).

Potter dan Perry (2009) menyatakan bahwa beberapa perubahan dalam kesehatan merupakan stressor dan dapat memengaruhi konsep diri individu, selanjutnya akan memengaruhi identitas dan penerimaan diri. Penyakit kronis seperti stroke akan membutuhkan perubahan dalam penerimaan diri penderitanya. Semakin banyak penyakit kronis yang menggangu kemampuan beraktivitas, maka akan semakin memengaruhi penerimaan diri individu. Sartain (dalam Andromeda, 2006) mendefinisikan penerimaan diri sebagai kesadaran seseorang untuk menerima dirinya sebagaimana adanya dan memahami dirinya seperti apa adanya. Individu yang memiliki penerimaan diri berarti telah menjalani proses yang menghantarkan dirinya pada pengetahuan dan pemahaman tentang dirinya sehingga dapat menerima dirinya secara utuh dan bahagia. Rezkiana dan Retnaningsih (2009) menyebutkan

INSAN Jurnal Psikologi dan Kesehatan Mental

2021, Vol. 6(1), 53-62

doi: 10.20473/jpkm.v6i12021.53-62

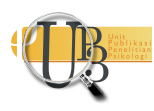


bahwa individu yang dapat memahami dirinya sendiri tidak akan hanya tergantung dari kemampuan intelektualnya saja, akan tetapi individu tersebut memiliki kepastian akan kelebihannya dan tidak mencela kekurangan dirinya. Individu yang memiliki penerimaan diri mengetahui potensi yang dimilikinya dan dapat menerima kelemahannya.

Sofwan (2010) menambahkan bahwa berbagai masalah psikologis, seperti mudah marah, cemas, gugup, cepat tersinggung dan merasa bosan yang dihadapi penderita akan menimbulkan stres bagi penderita. Kehidupan yang penuh stres akan berpengaruh terhadap kesehatan penderita meskipun telah diupayakan diet, latihan fisik maupun pemakaian obat-obatan dengan secermat mungkin. Tidak terjadi hal yang membuat keadaan semakin buruk, sehingga perlu adanya dukungan sosial dari keluarga dan orang-orang terdekat yang selalu memberikan dukungan-dukungan dan arahan positif, yang nantinya dapat memengaruhi kesembuhan penderita pascastroke.

Menurut House (dalam Puspita, 2012) dukungan sosial merupakan tingkat persepsi seseorang terhadap intensitas dukungan sosial yang diterimanya dari orang lain. Johnson dan Johnson (dalam Urbayatun, 2010) mengatakan bahwa dukungan sosial sebagai pertukaran sumber-sumber dengan saling mempertinggi kesejahteraan dan keberadaan orang lain yang bisa diandalkan untuk diminta bantuan, dorongan, penerimaan dan perhatian apabila individu mengalami kesulitan. Sarafino (1998) memaparkan lima jenis dukungan sosial yaitu dukungan emosional, dukungan instrumental, dukungan penghargaan, dukungan informasi dan dukungan jaringan sosial. Adicondro dan Purnamasari (2011) menyebutkan bahwa individu yang mendapatkan dukungan sosial yang tinggi dari keluarga akan banyak mendapatkan dukungan emosional, penghargaan, instrumental, dan informatif dari keluarganya. Apabila dukungan emosional tinggi, individu akan merasa mendapatkan dorongan yang tinggi dari anggota keluarga. Apabila penghargaan untuk individu tersebut besar, maka akan meningkatkan kepercayaan diri. Adanya dukungan sosial akan membantu para penderita pascastroke menghadapi tekanan psikologis sehingga stres yang tinggi tidak akan menimbulkan atau memperburuk penyakit (Nurbani, 2008).

Papalia, Olds dan Feldman (2007) menyatakan bahwa pemberian dukungan sosial dari orang terdekat dengan individu (significant other) dapat meningkatkan penerimaan diri individu dan mempercepat proses penyembuhan penyakit kardiovaskular seperti jantung dan stroke. Lebih lanjut Savitri (2005) menyatakan bahwa rasa aman, cinta dan kasih sayang tulus dari anggota keluarga maupun orang terdekat lainnya mampu membuat individu yang sakit merasa nyaman, tenang, tidak merasa takut, malu dan rendah diri apabila berhadapan dengan orang lain, merasa dirinya diperhatikan dan menganggap dirinya dapat sehat kembali seperti sedia kala. Berdasarkan uraian di atas maka penelitian ini bertujuan untuk mengetahui hubungan antara dukungan sosial dengan penerimaan diri pada penderita pascastroke. Hipotesis yang diajukan dalam penelitian ini adalah terdapat hubungan positif antara dukungan sosial dengan penerimaan diri pada penderita pascastroke.

\section{Desain Penelitian}

\section{E T O D E}

Penelitian ini merupakan penelitian kuantitatif dengan pendekatan korelasional. Artinya, penelitian ini bertujuan untuk menguji hubungan antar variabel dengan menguji hipotesis yang telah diajukan sebelumnya.

\section{Partisipan}

Kriteria partisipan penelitian ini yaitu penderita pascastroke yang pernah didiagnosa oleh dokter mengalami stroke, penderita dalam keadaan sadar dan dapat diajak berkomunikasi dan bertempat

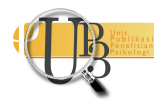


tinggal di kota Banda Aceh. Teknik sampling yang digunakan adalah incidental sampling yaitu teknik penentuan sampel berdasarkan kebetulan, yaitu siapa saja yang secara kebetulan bertemu dengan peneliti dapat digunakan sebagai sampel, apabila orang yang kebetulan ditemui itu cocok sebagai sumber data (Sugiyono, 2008). Sebanyak 75 penderita pascastroke terlibat dalam penelitian ini. Peneliti mengumpulkan data di beberapa layanan kesehatan seperti rumah sakit, Puskesmas, klinik, dan tempat umum lainnya. Setiap partisipan yang terlibat diberikan informasi lebih dulu terkait penelitian yang dilakukan. Kemudian setelah partisipan menyanggupi atau bersedia terlibat, maka peneliti meminta kesediaan partisipan mengisi lembar pernyataan dan mengisi kuesioner.

\section{Pengukuran}

Metode pengumpulan data yang digunakan dalam penelitian ini yaitu skala psikologi, yaitu; skala dukungan sosial dan skala penerimaan diri. Skala dukungan sosial disusun oleh peneliti berdasarkan jenis-jenis dukungan sosial yaitu dukungan emosional, dukungan penghargaan, dukungan instrumental, dukungan informasi dan dukungan jaringan sosial (Sarafino, 1998) yang berjumlah 20 pernyataan

Untuk mengukur variabel penerimaan diri menggunakan skala penerimaan diri yang disusun oleh Aidina (2013) berdasarkan aspek penerimaan diri oleh Shereer (dalam Cronbach, 1963) yaitu mempunyai keyakinan akan kemampuan untuk menghadapi kehidupan, menganggap dirinya berharga sebagai seorang manusia dan sederajat dengan orang lain, tidak menganggap dirinya aneh dan tidak ada harapan untuk ditolak orang lain, individu tidak merasa malu (self-conscious) dan mempunyai orientasi diri keluar, berani memikul tanggung jawab terhadap perilakunya, individu lebih suka mengikuti standar pribadi sesuai dengan keadaan dirinya daripada bersikap konform terhadap tekanan sosial, individu dapat menerima pujian atau celaan secara objektif, tidak mempermasalahkan keterbatasan yang dimilikinya atau mengingkari kelebihannya, dan tidak menyangkal impuls atau emosinya atau merasa bersalah atas hal-hal tersebut, yang berjumlah 37 pernyataan

Setiap pernyataan dalam skala dukungan sosial dan skala penerimaan diri, merupakan skala likert yang terdiri dari penyataan yang bersifat favourable dan unfavourable. Setiap pernyataan mempunyai 4 alternatif pilihan jawaban, berikisar antara "sangat tidak sesuai" (1) sampai dengan "sangat sesuai" (4). Semakin tinggi skor partisipan pada kedua skala dapat diartikan bahwa partisipan tersebut memiliki tingkat dukungan sosial dan penerimaan diri yang semakin tinggi.

Hasil uji reliabilitas terhadap skala dukungan sosial yang berjumlah 20 butir pernyataan menunjukkan nilai koefisien reliabilitas yang cukup baik $(\alpha=0,731)$, sedangkan reliabilitas skala penerimaan diri cenderung sangat baik $(\alpha=0,812)$. Artinya, kedua skala yang digunakan dalam penelitian ini memadai untuk digunakan mengukur variabel-variabel dalam penelitian ini.

\section{Analisis Data}

Data dalam penelitian ini dianalisis menggunakan uji statistik non parametrik dengan teknik korelasi Spearman's rho. Seluruh pengolahan data menggunakan bantuan SPSS for Windows versi 18.

\section{HAS I L PENELITIAN}

Untuk menguji hipotesis penelitian, yaitu ada hubungan antara dukungan sosial $(M=30 ; S D=10$; Min=53; Maks=66) dengan penerimaan diri $(M=37 ; S D=12,3$; Min=79; Maks=114), penulis melakukan uji korelasi. Sebelum memilih teknik korelasi yang sesuai, penulis melakukan uji asumsi, yaitu uji normalitas distribusi kedua variabel. Berdasarkan hasil uji normalitas, dapat disimpulkan bahwa INSAN Jurnal Psikologi dan Kesehatan Mental 2021, Vol. 6(1), 53-62

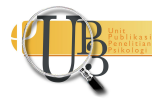


dukungan sosial memiliki sebaran yang normal (K-S-Z=0,926; $p=0,358$ ), namun penerimaan diri memiliki sebaran tidak normal (K-S-Z=2,873; $p=0,000)$. Oleh karena itu, penulis menggunakan teknik analisis Spearman's rho.

Analisis korelasi Spearman menunjukkan adanya korelasi yang positif antara dukungan sosial dengan penerimaan diri, dengan koefesien $(\rho(75)=0,47 ; p<0,05)$. Hal ini berarti Ho ditolak dan Ha diterima, artinya ada hubungan yang positif dan cenderung moderat antara dukungan sosial dengan penerimaan diri pada penderita pascastroke.

Tabel 1. Korelasi Aspek Dukungan Sosial dengan Penerimaan Diri

\begin{tabular}{lcc}
\hline \multicolumn{1}{c}{ Aspek Dukungan Sosial } & $\boldsymbol{\rho}$ & Nilai $\boldsymbol{p}$ \\
\hline Dukungan Emosional & 0,61 & 0,002 \\
Dukungan Penghargaan & 0,32 & 0,002 \\
Dukungan Instrumental & 0,60 & 0,000 \\
Dukungan Informasi & 0,36 & 0,002 \\
Dukungan Jaringan Sosial & 0,39 & 0,001 \\
\hline
\end{tabular}

Selain melakukan uji hipotesis untuk melihat hubungan antara dukungan sosial dengan penerimaan diri, peneliti juga melakukan analisis pada setiap aspek dukungan sosial untuk melihat aspek mana yang sangat berhubungan dengan penerimaan diri. Sesuai dengan Tabel 1, diketahui bahwa dukungan emosional $(\rho(75)=0,61 ; p=0,002)$ dan dukungan instrumental $(\rho(75)=0,60 ; p=0,000)$ merupakan dua aspek dukungan sosial dengan korelasi terkuat dengan penerimaan diri. Sebaliknya, dukungan penghargaan $(\rho(75)=0,32 ; p=0,002)$ dan dukungan informasi $(\rho(75)=0,36 ; p=0,002)$ merupakan aspek dukungan sosial dengan korelasi terendah dengan penerimaan diri.

\section{DISKUSI}

Hasil analisis data penelitian menunjukkan bahwa terdapat hubungan positif yang cenderung moderat antara dukungan sosial dengan penerimaan diri pada penderita pascastroke di Banda Aceh. Artinya, partisipan penelitian yang dukungan sosialnya cenderung kuat memiliki tingkat penerimaan diri yang lebih baik. Dengan demikian, temuan penelitian memberikan dukungan terhadap hipotesis yang menyatakan terdapat hubungan yang positif antara dukungan sosial dengan penerimaan diri pada penderita pascastroke di Banda Aceh.

Hasil uji hipotesis pada penelitian ini menunjukkan bahwa dukungan sosial merupakan salah satu faktor yang berperan terhadap pembentukan penerimaan diri. Adanya dukungan sosial yang baik dapat mengubah persepsi, pandangan, serta penerimaan diri pada penderita pascastroke. Hal ini sesuai dengan hasil penelitian yang dilakukan oleh Handayani, Ratnawati dan Helmi (1998) bahwa penerimaan diri secara positif berkorelasi dengan dukungan sosial dimana seseorang akan memiliki penerimaan diri yang lebih tinggi ketika mereka menerima dukungan sosial yang tinggi baik dari keluarga, teman atau orang lain yang signifikan dalam hidupnya.

Ismail (2008) juga menyatakan hal yang sama bahwa ada hubungan yang signifikan antara nilai individu, harga diri dan dukungan sosial yang diterima atau dirasakan oleh individu. Dukungan sosial menjadi salah satu faktor yang memengaruhi penerimaan diri individu karena individu yang menerima bantuan atau dukungan akan merasa dirinya dicintai dan berharga sehingga akan meningkatkan penerimaan dirinya. Pendapat lainnya disampaikan oleh Tajbakhsh dan Rousta (2012) yang menyatakan bahwa ada hubungan yang bermakna antara dukungan sosial dan penerimaan diri 
yaitu adanya dukungan keluarga, dukungan teman, dukungan dari lingkungan sosial, dukungan emosional dan dukungan instrumental akan memengaruhi penerimaan diri yang dimiliki individu.

Dukungan sosial sangat penting untuk menjaga fisik dan kesehatan psikologis individu terutama pada penderita pascastroke. Menurut Reitzes dan Mutran (dalam Erol \& Orth, 2011), ada hubungan timbal balik antara dukungan sosial, penerimaan diri dan kesehatan individu. Individu yang memiliki penerimaan diri tinggi menerima lebih banyak dukungan sosial dan mengalami sedikit stres sehingga akan meningkatkan kesehatan individu. Hal ini juga disampaikan oleh Taylor (2009) bahwa individu yang mendapat bantuan dan menerima dukungan sosial menguntungkan akan mengurangi risiko kematian dan meminimalkan komplikasi dari penyakit kronis atau dari kondisi medis yang lebih serius sehingga bermanfaat untuk kesehatan fisik dan mental individu tersebut. Menurut House, Landis dan Umberson (dalam Kim, Sherman \& Taylor, 2008), dukungan sosial efektif mengurangi tekanan psikologis seperti depresi dan kecemasan selama stres, mempercepat pemulihan dari penyakit, dan mengurangi risiko kematian akibat penyakit yang serius. Studi epidemiologis yang dilakukan oleh Kaplan dkk, Berkman dkk, Brummett dkk dan Rutledge dkk (dalam Uchino, 2009) juga menunjukkan bahwa individu dengan rendahnya tingkat dukungan sosial memiliki tingkat kematian yang lebih tinggi, terutama dari penyakit kardiovaskular seperti jantung, kanker dan stroke. Sebaliknya, individu yang memiliki dukungan sosial yang tinggi akan memiliki tingkat risiko kematian yang lebih rendah dari penyakit kardiovaskular.

Berdasarkan penelitian sebelumnya, banyak faktor yang memengaruhi penerimaan diri pada penderita pascastroke seperti pemahaman diri, adanya hal yang realistik, tidak adanya hambatan lingkungan, tingkah laku sosial yang sesuai, tidak adanya stres emosional, pengaruh keberhasilan yang dialami, baik secara kualitatif maupun kuantitatif, identifikasi dengan orang yang memiliki penyesuaian diri yang baik, perspektif diri, pola asuh dimasa kecil yang baik, dan konsep diri yang stabil (Hurlock, 1999), namun pada penelitian ini peneliti hanya sebatas mengkaji hubungan antara dukungan sosial dengan penerimaan diri pada penderita pascastroke. Schlutz (dalam Cronbach, 1963) mengatakan bahwa penerimaan diri memiliki hubungan yang erat dengan tingkat fisiologis. Tingkat fisiologis yang dimaksud adalah tingkat kesehatan individu yangdilihat dari kelancaran kerja organ tubuh dan aktivitas dasar, seperti makan, minum, istirahat dan kehidupan seksual, yang semuanya merupakan faktor penunjang utama kesehatan fisik. Individu yang bisa menerima keadaan dirinya tidak memiliki hambatan dalam hal ini. Hasil penelitian ini juga mendukung dugaan bahwa penerimaan diri penting karena merupakan asas bagi membentuk diri yang baik supaya dapat menerima kelebihan dan kekurangan yang ada.Penerimaan diri yang baik dapat mengawali diri dari unsur-unsur yang tidak baik serta menunjukkan tingkah laku yang terbaik dan dapat meningkatkan diri untuk menghadapi cobaan hidup (Calhoun \& Acocella, 1990).

Menurut Hurlock (1999) individu yang menerima dirinya memiliki penilaian yang realistik tentang sumber daya yang dimilikinya. Artinya, individu tersebut memiliki kepastian akan standar dan teguh dalam pendirian, serta mempunyai penilaian yang realistik terhadap keterbatasannya tanpa mencela diri. Jadi, orang yang memiliki penerimaan diri yang baik tahu kemampuan yang dimilikinya dan bisa mengatasi serta mengetahui cara mengelola masalah.Pendapat lainnya dikemukakan oleh Harter (dalam Santrock, 2007) yang menyatakan bahwa penerimaan diri individu memiliki hubungan yang erat dengan persepsi diri dimana penerimaan diri individu ikut dipengaruhi oleh adanya persepsi tentang penampilan fisik yang terus terjadi di sepanjang hidupnya. Hasil ini menguatkan pendapat Willi (dalam Destiani, 2008) menyatakan bahwa penerimaan diri yang tinggi akan memberikan sumbangan positif pada kesehatan mental. Artinya, ketika penderita pascastroke mempunyai penerimaan diri yang tinggi maka akan dapat memiliki kesehatan mental yang baik dan dapat memacu semangat untuk mencapai kesembuhan. 
Hasil analisis statistik terhadap kelima aspek dukungan sosial, menunjukkan bahwa dukungan emosional merupakan aspek yang memberikan kontribusi tertinggi terhadap tingginya penerimaan diri. Hal ini menunjukkan bahwa adanya perhatian emosional yang diekspresikan melalui rasa suka, cinta atau kesediaan untuk mendengarkan keluh kesah oleh orang-orang yang signifikan akan memberikan kontribusi terhadap tingginya penerimaan diri pada penderita pascastroke. Menurut Taylor (2009) dukungan emosional sangat penting diberikan oleh orang-orang yang intim atau dekat dengan individu, dukungan emosional yang diberikan oleh teman dan keluarga dapat membuat individu yang dirawat merasa bahwa dirinya adalah orang yang berharga sehingga akan meningkatkan penerimaan dirinya. Hal senada juga disampaikan oleh Brannon dan Feist (2009) yang menyatakan bahwa dukungan emosional sangat berguna bagi penderita pascastroke jika diberikan oleh keluarga dan teman-teman yang berada di lingkungan terdekatnya, sehingga dengan adanya dukungan emosional tersebut akan membuat penderita pascastroke lebih dapat menyesuaikan diri dengan kondisinya, merasa dirinya berharga atau bernilai dan menerima diri apa adanya.

Selain aspek dukungan emosional, aspek dukungan instrumental juga memberikan konstribusi terhadap tingginya penerimaan diri pada penderita pascastroke. Hal ini menunjukkan bahwa adanya bantuan langsung dalam bentuk bantuan fisik seperti pelayanan dan bantuan finansial berupa penyediaan materi, pinjaman uang atau pemberian barang dapat memberikan kontribusi terhadap tingginya penerimaan diri pada penderita pascastroke. Adanya bantuan instrumental tersebut maka dapat membantu penderita pascastroke memenuhi segala kebutuhannya selama masa penyembuhan. Hal ini sesuai dengan pendapat Sarafino (1998) yang menyatakan bahwa bentuk dukungan instrumental dapat mengurangi kecemasan dan menimbulkan perasaan optimis karena individu dapat langsung memecahkan masalahnya yang berhubungan dengan materi. Dukungan instrumental sangat diperlukan dalam mengatasi masalah yang dianggap masih dapat dikontrol. Dukungan instrumental sangat diperlukan terutama dalam mengatasi masalah dengan lebih mudah.

Selanjutnya, aspek yang memberikan kontribusi terkecil terhadap tingginya penerimaan diri adalah dukungan penghargaan. Hal ini menunjukkan bahwa dukungan penghargaan adalah dukungan yang paling sedikit diterima atau dirasakan oleh penderita pascastroke dibandingkan keempat aspek dukungan sosial lainnya. Taylor (2009) menyatakan bahwa dukungan sosial mungkin tidak akan efektif jika jenis dukungan yang diberikan bukanlah jenis dukungan yang dibutuhkan. Selain itu, jika jenis dukungan yang diterima tersebut diberikan oleh orang yang kurang tepat maka dukungan tersebut tidak akan membantu individu yang menerimanya bahkan justru akan ditolak. Misalnya, dukungan emosional lebih bermanfaat jika diberikan oleh orang yang intim atau dekat sedangkan dukungan informasi lebih bermanfaat jika diberikan oleh dokter atau oleh sesama penderita penyakit kronis. Berdasarkan uraian diatas dapat disimpulkan bahwa dukungan sosial memiliki peran terhadap tinggi rendahnya penerimaan diri pada penderita pascastroke. Keduanya memiliki korelasi positif, artinya jika tingkat dukungan sosial tinggi maka tingkat penerimaan diri akan tinggi begitu pula sebaliknya jika tingkat dukungan sosial rendah maka tingkat penerimaan diri pada penderita pascastroke juga akan rendah.

Sebagai akhir pembahasan, perlu diketahui bahwa hasil penelitian ini memiliki beberapa keterbatasan. Pertama, tidak adanya data konkrit tentang jumlah populasi penderita pascastroke di Banda Aceh sehingga jumlah sampel dalam penelitian ditentukan berdasarkan waktu lamanya pelaksanaan penelitian berlangsung. Kedua, pernyataan pada skala dukungan sosial disusun untuk penderita pascastroke yang masih memiliki pasangan, sehingga kurang tepat apabila diberikan kepada sampel yang sudah tidak memiliki pasangan atau sampel yang tidak memiliki pasangan. Ketiga, keterbatasan pengetahuan peneliti tentang prosedur administrasi di beberapa lokasi pengumpulan data yang menyebabkan minimnya jumlah partisipan yang terlibat karena dilakukan dengan pendekatan personal saat partisipan sedang menunggu.

INSAN Jurnal Psikologi dan Kesehatan Mental

2021, Vol. 6(1), 53-62

doi: 10.20473/jpkm.v6i12021.53-62 


\section{S I M P U L A N}

Hasil penelitian ini menunjukkan bahwa terdapat hubungan yang positif yang cenderung moderat antara dukungan sosial dengan penerimaan diri pada penderita pascastroke. Artinya, partisipan penelitian yang dukungan sosialnya cenderung kuat memiliki tingkat penerimaan diri yang lebih baik. Selain itu, diketahui bahwa dukungan emosional dan dukungan instrumental merupakan dua aspek dukungan sosial dengan korelasi terkuat dengan penerimaan diri. Sebaliknya, dukungan penghargaan dan dukungan informasi merupakan aspek dukungan sosial dengan korelasi terendah dengan penerimaan diri.

Saran penulis bagi peneliti selanjutnya adalah sebagai berikut; peneliti selanjutnya sebaiknya mempertimbangkan variabel psikologis lainnya yang memengaruhi penerimaan diri pada penderita pascastroke seperti citra tubuh, harga diri dan kesejahteraan psikologis dengan menggunakan sampel yang berbeda, misalnya penderita kanker, jantung, paru-paru dan lain-lain. Selanjutnya, peneliti selanjutnya sebisa mungkin dapat memperoleh data yang konkrit tentang jumlah populasi sehingga penentuan jumlah sampel penelitian dapat lebih representatif. Selain itu, dalam pelaksanaan penelitian disarankan menggunakan bantuan orang lain dalam pengambilan data agar penelitian yang dilakukan dapat lebih efektif dan efisien. Pernyataan yang disusun dalam skala dukungan sosial sebaiknya dapat diberikan kepada individu yang tidak memiliki pasangan dan individu yang sudah tidak memiliki pasangan serta diharapkan kepada peneliti selanjutnya agar lebih memahami tentang prosedur pengajuan izin penelitian di instansi terkait guna untuk mempermudah peneliti untuk memperoleh sampel yang lebih banyak.

\section{DEKLARASI POTENSI TERJADINYA KONFLIK KEPENTINGAN}

Maya Khairani, Afriana Selvi AS, dan Kartika Sari tidak bekerja, menjadi konsultan, memiliki saham, atau menerima dana dari perusahaan atau organisasi manapun yang mungkin akan mengambil untung dari diterbitkannya naskah ini.

\section{PUST AKA ACUAN}

Adicondro, N., \& Purnamasari, A. (2011). Efikasi diri, dukungan sosial keluarga dan self-regulated learning pada siswa kelas VIII. Humanitas, 8(1), 18-27.

Aidina, W. (2013). Hubungan antara penerimaan diri dengan optimisme menghadapi masa depan pada remaja di panti asuhan. Skripsi. Banda Aceh: Universitas Syiah Kuala.

Andromeda,Y. (2006). Penerimaan diri wanita penderita kanker payudara ditinjau dari kepribadian tahan banting (hardiness) dan status pekerjaan. Skripsi (Tidak Diterbitkan). Fakultas Psikologi Universitas Islam Indonesia.

Buku Induk Rumah Sakit Umum Daerah Zainal Abidin. (n.d.). Banda Aceh.

Brannon, L., \& Feist, J. (2009). Health Psychology: An introduction to behaviour and health: An introduction to behaviour and health. International Journal of Business Studies, 4(2), 87-104.

Calhoun, J.,F., \& Acocella, J.R. (1990). Psychology of adjustment and human relationships. New York: McGraw-Hill Publishing Company.

Cronbach. (1963). Educational psychology (edisi kedua). New York: Harcourt, Brace \& World, Inc.

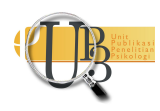


Darusman. (2008). Stroke. Diakses $20 \quad$ Juni 2012 melalui https://kesehatan.kompas.com/read/2008/11/04/09021034/

Destiani N.W., (2008). Penerimaan diri pada mantan PSK. Skripsi. Solo: Universitas Muhammadiyah Surakarta.

Emery, R. E. \& Oltmanns, T. F. (2000). Essentials Of Abnormal Psychology. New Jersey: Prentice Hall, Inc.

Erol, R. Y. \& Orth, U. (2011). Self-acceptance development of age 14 to 30 years: a longitudinal study. Journal of Personality and Social Psychology, 101(3), 607-619.

Feigin, V. (2006). Panduan bergambar tentang pencegahan dan pemulihan stroke. Jakarta: Kelompok Gramedia.

Ginsberg. (2008). Lecture notes neurologi. Edisi ke-8. Jakarta: Erlangga.

Handayani, M. M., Ratnawati, S., \& Helmi, A. F. (1998). Efektivitas pelatihan pengenalan diri terhadap peningkatan penerimaan diri dan harga Diri. Jurnal Psikologi, 2(2), 47-55.

Hurlock, E. B. (1999). Psikologi perkembangan suatu pendekatan sepanjang rentang kehidupan. Penerjemah: Isti Widayanti \& Soedjarwo. Jakarta: Erlangga.

Ismail, A. (2008). Hubungan antara Dukungan sosial dengan penerimaan diri ibu dari anak Autis. Skripsi. Semarang: Program Studi Psikologi UNIKA Soegijapranata.

Kim, H. S., Sherman, D. K \& Taylor, S. E. (2008). Culture and social support, American Psychologist, 63(6), 518-526.

Mahendra, B \& Rachmawati, E. (2007). Atasi stroke dengan tanaman obat. Depok: Swadaya.

Nurbani, F. (2008). Social Support In ODHA. Skripsi. Jakarta: Universitas Gunadarma.

Papalia, D. E., Olds, S. W., \& Feldman, R. D. (2007). Human Development (10 ${ }^{\text {Th }}$ edition). Penerjemah: Brian Marswendy. New York: McGraw-Hill Companies, Inc.

Potter, A. P \& Perry, A. G. (2009). Fundamental Keperawatan Edisi 7 Jilid 1 \& 2. Jakarta: Salemba Medika.

Price, S. A., \& Wilson, L. M. (2005). Patofisiologi. konsep klinis proses-proses penyakit. Edisi ke-6. Jakarta: EGC.

Puspita, M. D. (2012). Hubungan antara dukungan sosial dan makna kerja sebagai panggilan (calling) dan keterikatan kerja. Jurnal ilmiah mahasiswa Universitas Surabaya, 1(1), 1-17.

Riset Kesehatan Dasar. (2007). Laporan hasil riset kesehatan dasar (RISKESDAS) Nasional 2007. Badan penelitian dan pengembangan kesehatan RI: Jakarta. Diakses pada Mei 2010.

Rezkiana, U., \& Retnaningsih. (2009). Penerimaan diri pada remaja penderita leukemia. Jurnal Psikologi, 2(2), 144-122.

Sarafino, E.P. (1998). Health Psychology: Biopsychosocial Interaction (2 $2^{\text {Th }}$ edition). New York: John Wiley \& Sons, Inc.

Savitri, T . (2005). Aku dan lupus. Jakarta: Puspa Swara.

Sofwan, R. (2010). Stroke dan rehabilitasi pascastroke. Jakarta: BIP.

Sugiyono. (2008). Metode penelitian kuantitatif, kualitatif dan R\&D. Bandung: Alfabeta.

Tajbakhsh, G., \& Rousta, M. (2012). The effect of social support on self-esteem. Journal of Basic and Applied Research, 2(11), 11266-11271.

INSAN Jurnal Psikologi dan Kesehatan Mental

2021, Vol. 6(1), 53-62

doi: 10.20473/jpkm.v6i12021.53-62 
Taylor, S, E. (2009). Health Psychology. University of California, Los Angeles. McGraw-Hill.

Uchino, B. N. (2009). Understanding the links between social support and physical health. Journal of The Association For Psychological Science (aps), 4(3), 19-23.

Urbayatun, S. (2010). Dukungan sosial dan kecenderungan depresi post-partum pada ibu primipara di daerah gempa Bantul. Fakultas Psikologi Universitas Ahmad Dahlan. Humanitas 7(2), 115-122. 